\title{
PERSPEKTIF PERSEKITARAN ROGERS DENGAN PENERIMAAN TEKNOLOGI DAN UMUR SEBAGAI MODERATOR
}

\section{ROGERS'S ENVIRONMENTAL PERSPECTIVE WITH ACCEPTANCE OF TECHNOLOGY AND AGE AS A MODERATOR}

\author{
SURENDRAN SANKARAN \\ NORAZLINDA SAAD \\ Pusat Pengajian Pendidikan dan Bahasa Moden \\ Universiti Utara Malaysia
}

\begin{abstract}
Abstrak
Kajian ini bertujuan untuk mengenal pasti pengaruh faktor perspektif persekitaran Rogers dengan penerimaan teknologi perisian kursus serta mengkaji peranan umur sebagai moderator. Kajian ini menggunakan kaedah tinjauan. Populasi kajian ini adalah 490 orang guru Matematik yang mengajar Tingkatan 1 di Sekolah Menengah Kebangsaan harian. Sampel kajian ini telah dipilih dengan menggunakan persampelan kluster dan persampelan rawak. Soal selidik kajian ini diadaptasi dari sumber-sumber lain dan mengandungi 15 item. Soal selidik kajian ini mempunyai tahap kebolehpercayaan yang tinggi dengan nilai Alpha 0.96. Data kuantitatif dianalisis dengan menggunakan statistik deskriptif, Korelasi Pearson dan Analisis Regresi Berganda. Berdasarkan Jadual Peringkat Penerimaan oleh Moersch (1995), guru Matematik yang mengajar Tingkatan 1 berada pada peringkat penerapan. Dapatan kajian menunjukkan bahawa faktor perspektif persekitaran mempunyai pengaruh yang signifikan terhadap tahap penerimaan perisian kursus. Analisis regresi berganda hierarki menunjukkan pemboleh ubah umur, sebagai moderator telah memberi pengaruh yang signifikan terhadap hubungan antara faktor perspektif persekitaran dengan tahap penerimaan perisian kursus. Kajian ini menjelaskan bahawa interaksi antara umur guru dengan faktor perspektif persekitaran perlu diberi penekanan dalam pendifusian inovasi tersebut supaya dapat meningkatkan lagi tahap penerimaan perisian kursus.
\end{abstract}

Kata kunci: Pendifusian teknologi, perisian kursus, tahap penerimaan. 


\begin{abstract}
Purpose - This study aimed to identify the influence of Rogers's environmental perspective factors with the adoption of courseware technology and examined the role of age as a moderator.

Design - This study used a survey method. The population of this study consisted of 490 Form 1 Mathematics teachers of national secondary schools. The sample was selected by using cluster and random sampling. The questionnaire was adapted from other sources and contained 15 items. The questionnaire had a high acceptance level (the value of Alpha $=0.96$ ). The quantitative data was analysed using descriptive statistics, correlation testing and multiple regression analysis. Based on the Table Level Acceptance by Moersch (1995), a mathematics teacher who taught Form 1 was at the application level.
\end{abstract}

Findings - The findings showed that the environmental perspective factor had a significant influence on the level of courseware acceptance. The hierarchical multiple regression analysis showed that age as a moderator pemboleh ubah had a significant influence on the relationship between the environmental perspective factors and the level of courseware acceptance.

Significance - The study also revealed that the interaction between teacher's age and perspective environmental factors should be emphasized in the diffusion of innovation in order to increase the level of courseware acceptance.

Keywords: Diffusion of technology, courseware, level of acceptance.

\title{
Pengenalan
}

Pengajaran berbantukan Teknologi Maklumat dan Komunikasi (ICT) melalui penerokaan sumber digital boleh membantu dalam meningkatkan minat pelajar serta menjadikan proses pengajaran dan pembelajaran (P\&P) lebih berkesan. Oleh itu, pihak Kementerian Pelajaran Malaysia (KPM) telah membelanjakan RM580 juta untuk menyediakan pelbagai bahan teknologi untuk digunakan dalam P \& $\mathrm{P}$, memberikan latihan kepada guru dan menyediakan kemudahan. Bagi tujuan membantu menyepadukan ICT dalam P\&P, guruguru dibekalkan dengan perisian kursus. Pihak KPM berpendapat 
pengintegrasian perisian kursus boleh membawa perubahan yang besar dalam kaedah pengajaran guru dan cara belajar pelajar (KPM, 2001). Roblyer dan Edwards (2000) dan Lee, Cheung dan Chen (2005) menyatakan perisian kursus mempunyai potensi untuk meningkatkan mutu P\&P di samping menggalakkan interaksi antara pelajar melalui pelbagai aktiviti.

Pelbagai usaha telah dilaksanakan untuk meningkatkan pengintegrasian ICT dalam P\&P. Namun, isu sejauh mana proses pendifusian memberi kesan kepada penerimaan dan pengintegrasian ICT masih dipersoalkan. Kajian oleh Azizah (2006), Fong (2006), Pusat Perkembangan Kurikulum (2006) dan Bee dan Chia (2008) menunjukkan tahap penerimaan perisian kursus dalam P\&P didapati masih berada pada tahap yang rendah tidak digunakan sepenuhnya dalam pengajaran. Teori Pendifusian oleh Rogers (2003) menjelaskan bahawa persepsi dan sokongan persekitaran dari segi Sokongan dan Masa amat mempengaruhi pendifusian sesuatu inovasi. Oleh yang demikian, kajian ini sangat perlu untuk mengenal pasti pengaruh faktor perspektif persekitaran Rogers terhadap penerimaan perisian kursus dalam kalangan guru Matematik yang mengajar Tingkatan 1. Selain itu, kajian ini juga akan menguji pemboleh ubah umur sebagai moderator terhadap hubungan antara faktor perspektif persekitaran Rogers dengan penerimaan perisian kursus.

\section{Objektif Kajian}

Objektif kajian ini secara umumnya untuk meninjau hubungan antara faktor-faktor pendifusian dengan penerimaan guru Matematik terhadap perisian kursus. Secara khususnya kajian ini bertujuan untuk:

1. mengenal pasti pengaruh faktor perspektif persekitaran Rogers terhadap penerimaan perisian kursus; dan

2. menentukan pengaruh pemboleh ubah umur sebagai moderator terhadap hubungan antara faktor perspektif persekitaran Rogers dengan penerimaan perisian kursus.

\section{Kerangka Kajian}

Kerangka kajian dalam Rajah 1 dibina berasaskan kepada Teori Pendifusian oleh Rogers (2003) dan Technology Acceptance Model (1989). Faktor Perspektif Persekitaran Rogers (Sokongan dan Masa) dipilih berdasarkan Teori Pendifusian oleh Rogers (2003). Teori Pendifusian 
Rogers (2003) menjelaskan bahawa penerimaan sesuatu inovasi juga dipengaruh oleh sokongan persekitaran tempat inovasi tersebut disebarkan. Sokongan persekitaran dapat dilihat dari aspek sokongan pihak pengurusan, sokongan kemudahan dan sokongan teknikal di samping keperluan masa untuk membolehkan guru menerima sesuatu inovasi dan mengintegrasikannya dalam P\&P. Dalam kajian ini, perspektif persekitaran diwakili oleh faktor-faktor sokongan dan masa untuk mengkaji hubungan perspektif persekitaran dengan penerimaan perisian kursus.

Berdasarkan persoalan kajian, di samping faktor-faktor pendifusian, pemboleh ubah demografi iaitu umur juga mempengaruhi tahap penerimaan sesuatu inovasi teknologi (Shahrinaz, 2009; Siti Norazlina, 2008). Oleh yang demikian, pemboleh ubah umur dijadikan sebagai pemboleh ubah moderator dalam kajian ini.

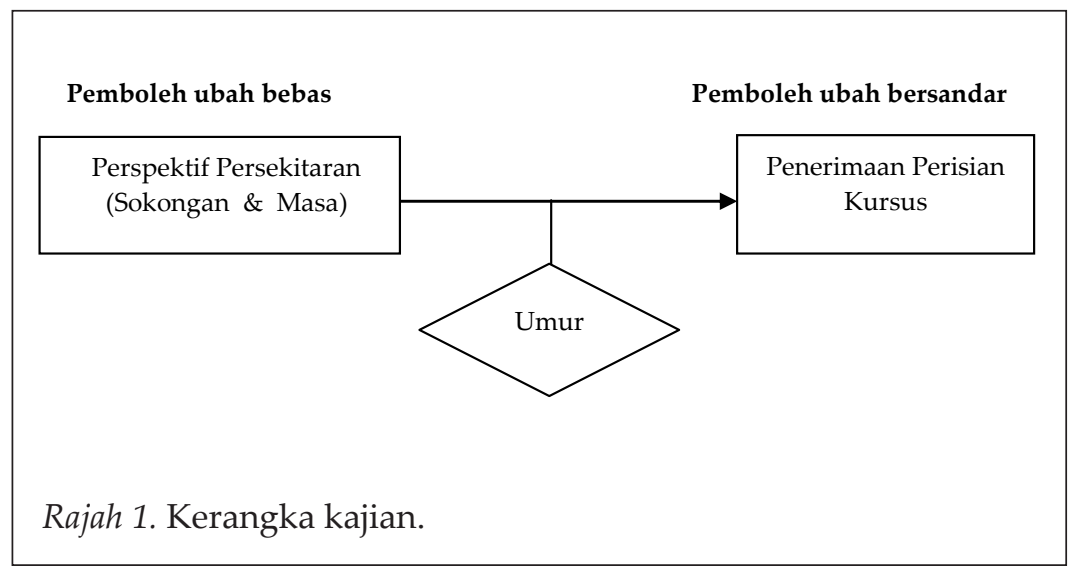

\section{Definisi operasional}

Dalam kajian ini, terdapat istilah-istilah yang perlu diberi definisi untuk pemahaman umum tentang sesuatu makna dan konsep. Definisi istilah tersebut adalah seperti berikut:

\section{Pendifusian}

Konsep pendifusian didefinisikan sebagai satu proses yang menerangkan bagaimana sesuatu inovasi dikomunikasikan melalui pelbagai saluran media pada jangka masa tertentu dalam sesebuah sistem sosial. 


\section{Perspektif persekitaran}

Perspektif persekitaran pula merujuk kepada persepsi dan sokongan persekitaran dari segi sokongan dan masa.

\section{Faktor sokongan}

Latihan tentang cara penggunaan perisian kursus dalam P\&P, maklumat atau bahan-bahan yang boleh didapati daripada perisian kursus dan sokongan pihak pentadbiran dalam menggalakkan guru untuk menggunakan perisian kursus dalam P\&P.

\section{Faktor masa}

Masa untuk mempelajari cara menggunakan perisian kursus dan membuat persediaan untuk mengajar dengan menggunakan teknologi tersebut.

\section{Penerimaan perisian kursus}

Pengintegrasian perisian kursus dalam proses P\&P mata pelajaran Matematik.

\section{Perisian kursus}

Bahan pengajaran dalam bentuk CD-ROM yang dibekalkan untuk penggunaan guru oleh Bahagian Teknologi Pendidikan untuk mata pelajaran Matematik. Perisian kursus yang dibangunkan adalah bersifat resource based berdasarkan kurikulum dan bertujuan membantu pelajar dalam aspek pembelajaran. Bahan pengajaran ini menggabungkan elemen-elemen teks, video, grafik, animasi dan audio di dalam komputer dan pengguna boleh berinteraksi dengannya (Henderson, \& Putt, 1996).

\section{Sekolah Menengah Kebangsaan Harian}

Sekolah menengah kebangsaan (SMK) harian yang ditentukan berdasarkan data daripada JPN Kedah.

\section{Sorotan Kajian}

Persoalan kajian ini akan memberi fokus kepada teori pendifusian inovasi, teori, faktor-faktor pendifusian dan penerimaan inovasi. 


\section{Pendifusian Inovasi}

Pendifusian inovasi merupakan suatu proses cara inovasi disebarkan melalui saluran komunikasi tertentu kepada ahli-ahli dalam suatu sistem sosial (Rogers, 2003). Rogers menjelaskan ahli Teknologi Pendidikan bukan sahaja perlu mereka sesuatu produk yang baik malah perlu memikirkan cara untuk mendifusikan produk tersebut. Seseorang yang bakal menerima sesuatu inovasi perlu memahami dengan lebih mendalam tentang inovasi tersebut sebelum membuat keputusan untuk menerima inovasi berkenaan atau sebaliknya.

\section{Teori Pendifusian Rogers (2003)}

Teori Pendifusian Rogers memberi penekanan bahawa di samping mereka bentuk sesuatu inovasi yang baik, ahli teknologi pendidikan juga perlu memikirkan cara untuk mendifusikan inovasi tersebut. Perkara utama yang perlu dititikberatkan dalam pendifusian inovasi ialah cara sesuatu inovasi itu diterima dan sebab penerimaan inovasi ini berlaku pada kadar yang berbeza.

Berdasarkan teori tersebut proses pendifusian terbahagi kepada lima langkah iaitu pengetahuan, pujukan, membuat keputusan, pelaksanaan dan pengesahan. Seseorang yang bakal menerima sesuatu inovasi perlu memahami dengan lebih mendalam tentang inovasi tersebut serta cara penggunaannya sebelum membuat keputusan untuk menerima inovasi tersebut atau sebaliknya. Apabila sesuatu komuniti masyarakat telah bersedia untuk menerima inovasi yang baharu maka pereka bentuk perlu merancang cara untuk menyalurkan inovasi tersebut kepada masyarakat.

Secara keseluruhannya, Teori Rogers (2003) membincangkan dengan mendalam bagaimana sesuatu yang baharu sama ada dalam bentuk idea, teknologi, barangan atau teknik berkembang dalam berbagaibagai khalayak sehingga diterima dan diamalkan sepenuhnya oleh masyarakat. Dalam konteks kajian ini, Teori Pendifusian Rogers digunakan untuk mengkaji penerimaan perisian kursus dalam P\&P dalam kalangan guru Matematik dan faktor-faktor yang mempengaruhi keputusan guru Matematik untuk menerima inovasi perisian kursus.

\section{Perspektif Persekitaran Rogers}

Perspektif Persekitaran pula merujuk kepada persepsi dan sokongan persekitaran dari segi sokongan dan masa. Farquhar dan Surry (1997) 
berpendapat gabungan faktor organisasi dan faktor penerimaan sesuatu inovasi oleh individu amat mempengaruhi proses pendifusian dan penggunaan sesuatu produk pendidikan. Webb (2011), Askar dan Usluel (2005) dan Groves dan Zemel (2000) menjelaskan bahawa aspek sokongan seperti latihan tentang cara penggunaan, kekurangan guru, bahan yang boleh didapati, peruntukan bajet, dan sokongan pihak pentadbiran mempengaruhi penerimaan teknologi.

Groves dan Zemel (2000) apabila membincangkan tentang faktor yang mempengaruhi penggunaan teknologi dan halangan penggunaan teknologi mendapati masa interaksi memainkan peranan yang penting dalam mempengaruhi penggunaan sesuatu inovasi kerana guru memerlukan masa untuk mempelajarinya. Oleh yang demikian, guru perlu diberi masa yang mencukupi untuk membuat persediaan mengajar dengan menggunakan perisian kursus. Beban tugas guru yang mengajar mata pelajaran Matematik, Sains dan Teknologi perlu dikurangkan supaya mereka mempunyai masa untuk meneroka inovasi baru dan mengaplikasikannya dalam P\&P (Poe, 2000).

Dalam konteks kajian ini, Perspektif Persekitaran Rogers akan digunakan untuk mengenal pasti bagaimana pemboleh ubah sokongan dan masa dapat mempengaruhi tahap penerimaan perisian kursus dalam kalangan guru Matematik di SMK Harian. Sokongan pihak sekolah dan masa yang cukup akan menggalakan guru untuk menerima dan mengintegrasikan perisian kursus dalam P\&P mata pelajaran Matematik.

\section{Umur sebagai Moderator}

Kajian oleh Norhayati (2000) ke atas guru-guru yang mengajar mata pelajaran komputer dalam pendidikan menunjukkan latar belakang guru amat mempengaruhi tahap penerimaan komputer dalam P\&P. Selain itu, Shahrinaz (2009) telah membuat kajian tentang penerimaan blog sebagai alat pembelajaran dalam kalangan pelajar universiti swasta. Beliau mendapati faktor latar belakang responden seperti jantina, umur dan pengalaman yang dijadikan sebagai pemboleh ubah moderator memberi sumbangan kepada peningkatan dalam niat pelajar untuk menerima teknologi blog sebagai alat pembelajaran.

Dengan itu, kajian-kajian lepas menunjukkan pemboleh ubah umur telah mempengaruhi penerimaan sesuatu inovasi teknologi. Dalam kajian ini, pemboleh ubah umur digunakan sebagai moderator untuk 
melihat pengaruh pemboleh ubah tersebut terhadap hubungan antara faktor perspektif persekitaran dan penerimaan perisian kursus.

\section{Tahap Penerimaan Perisian Kursus}

Penerimaan perisian kursus multimedia interaktif merupakan pemboleh ubah bersandar dalam kajian ini. Konsep penerimaan diterangkan sebagai pengintegrasian perisian kursus dalam proses P\&P oleh guru. Tahap Penerimaan diukur berdasarkan peringkat penerimaan yang dicadangkan oleh Moersch (1995). Peringkat penerimaan tersebut menggunakan 7 skala (0-6) iaitu bermula dengan peringkat tidak menggunakan teknologi (peringkat 0) sehingga peringkat pengembangan teknologi (peringkat 6). Menurut Moersch (1995), seorang guru akan beralih daripada satu peringkat ke satu peringkat berdasarkan penggunaan teknologi dalam P\&P. Peningkatan penerimaan teknologi dalam pengajaran akan menyebabkan guru mencapai peringkat yang lebih tinggi dan pengajaran berasaskan guru akan berubah kepada pengajaran berasaskan pelajar.

\section{Metodologi Kajian}

Kajian ini mengadaptasi pendekatan kuantitatif dengan menggunakan kaedah tinjauan. Rasional pemilihan pendekatan kuantitatif adalah pendekatan ini melibatkan pengumpulan dan analisis data numerikal untuk mendapat celik akal bagaimana satu pemboleh ubah mempengaruhi pemboleh ubah lain (Wiersma, 2000). Sementara, kaedah kajian tinjauan pula didapati sesuai kerana kaedah ini dianggap salah satu cara untuk mengumpul maklumat untuk menjelaskan ciri-ciri pelbagai data. Maklumat yang diperoleh digunakan untuk menyatakan keadaan sebenar sesuatu perkara yang berkaitan dengan sesuatu komuniti dalam konteks tersendiri (Wiersma, 2000).

Populasi kajian ini terdiri daripada 490 orang guru Matematik yang mengajar Tingkatan 1 di seluruh SMK harian di negeri Kedah. Sampel kajian ini dipilih dengan menggunakan pensampelan kluster dan pensampelan rawak. Berdasarkan Jadual Penentuan Saiz Sampel Krejcie dan Morgan (1970), bilangan sampel yang sesuai untuk populasi guru Matematik seramai 490 orang ialah 217 orang. Dalam kajian ini, seramai 240 orang guru Matematik dipilih sebagai sampel 
kajian di mana sampel guru Matematik diberikan nombor secara berturutan. Contohnya, daripada nombor 001 hingga 010. Pemilihan empat orang guru Matematik yang mengajar Tingkatan 1 dibuat secara cabutan undi.

Soal selidik telah digunakan sebagai alat ukur untuk mengutip data. Menurut Sekaran (2003), kaedah tinjauan menggunakan soal selidik sebagai alat kajian adalah bersifat logik, saintifik dan khusus. Oleh kerana soal selidik merangkumi bidang yang luas dan boleh dirangka dengan mudah dan jelas, responden boleh menjawabnya tanpa memerlukan kehadiran penyelidik. Set soal selidik ini mengandungi tiga bahagian iaitu Bahagian A berkaitan dengan latar belakang responden, Bahagian B berkaitan dengan faktor perspektif persekitaran Rogers (Sokongan \& Masa) dan Bahagian C yang mengandungi item berkaitan penerimaan perisian kursus. Item-item dalam kajian ini telah disemak dari segi kesahan kandungan dan kebolehpercayaan. Analisis kajian sebenar menunjukkan soal selidik ini mempunyai nilai kebolehpercayaan yang tinggi iaitu $\alpha=0.96$. Jadual 1 menunjukkan sumber soal selidik kajian ini.

Jadual 1

Sumber Instrumen Kajian

\begin{tabular}{lccc}
\hline Dimensi Utama & Bil. Item & Sumber & $\alpha$ \\
\hline $\begin{array}{l}\text { Perspektif Persekitaran Rogers } \\
\text { (Sokongan \& Masa) }\end{array}$ & 7 & Poe (2000) & 0.89 \\
Penerimaan Perisian Kursus & 25 & Moersch (2001) & 0.91 \\
Jumlah & 32 & & 0.96 \\
\hline
\end{tabular}

Data yang dikumpul diuji dari segi perhubungan yang linear, normal, homoskedastisiti, ungkapan ralat adalah tak bersandar, multikoliniriti dan outliers supaya data ini memenuhi andaianandaian korelasi dan regresi berganda. Program "Statistical Package for Social Science" (SPSS) versi 15.0 digunakan untuk ujian signifikan bagi menjawab persoalan kajian. Statistik deskriptif seperti frekuensi, min dan sisihan piawai telah digunakan untuk menerangkan ciriciri responden kajian dan untuk menentukan peringkat penerimaan perisian kursus. Statistik inferensi iaitu analisis regresi berganda telah digunakan untuk mengkaji pengaruh yang signifikan dan kesan pemboleh ubah moderator. 


\section{Dapatan dan Perbincangan}

\section{Latar Belakang Responden}

Dapatan kajian (Jadual 2) menunjukkan responden guru perempuan (65.6 peratus) adalah lebih ramai daripada guru lelaki (34.4 peratus). Dari segi umur pula, guru yang berumur antara 40 hingga 49 dan 30 hingga 39 tahun merupakan responden yang paling ramai terlibat dalam kajian ini iaitu masing-masing 85 dan 84 orang. Guru yang berumur 20 hingga 21 tahun merupakan responden yang paling rendah (9.6 peratus). Data tentang pengalaman mengajar menunjukkan guru yang telah mengajar lebih daripada 10 tahun merupakan responden yang paling ramai iaitu 147 orang. Seramai 47 orang guru mempunyai pengalaman mengajar antara 5 hingga 10 tahun dan 24 orang guru lagi mempunyai pengalaman mengajar kurang daripada lima tahun. Bilangan guru Matematik berdasarkan lokasi sekolah menunjukkan 110 orang guru adalah dari sekolah bandar dan 108 orang guru adalah dari sekolah luar bandar.

Jadual 2

Latar Belakang Responden Kajian

\begin{tabular}{lcc}
\hline \multicolumn{1}{c}{ Pemboleh ubah } & Frekuensi & $\%$ \\
\hline Jantina & 75 & 34.4 \\
$\quad$ Lelaki & 143 & 65.6 \\
Perempuan & & \\
& & \\
Umur & 21 & 9.6 \\
20 - 29 tahun & 84 & 38.5 \\
30 - 39 tahun & 85 & 39.0 \\
40 - 49 tahun & 28 & 12.8 \\
50 - 58 tahun & & \\
& & \\
Pengalaman Mengajar & 24 & 11.0 \\
Kurang dari 5 tahun & 47 & 21.6 \\
5 - 10 tahun & 147 & 67.4 \\
Lebih dari 10 tahun & & \\
$\quad$ & 110 & 50.5 \\
Lokasi Sekolah & 108 & 49.5 \\
$\quad$ Sekolah Bandar & & \\
Sekolah Luar Bandar & & \\
\end{tabular}




\section{Dapatan Deskriptif Penerimaan Perisian Kursus}

Dapatan kajian menunjukkan tahap penerimaan guru Matematik yang mengajar Tingkatan 1 berada pada peringkat ketiga iaitu Peringkat Penerapan (Min =3.42). Berdasarkan Peringkat Penerimaan yang dicadangkan oleh Moersch (1995), pada peringkat ini guru-guru mampu menggunakan aplikasi teknologi seperti pangkalan data, spreadsheets, persembahan, pakej grafik, kalkulator, penggunaan multimedia dan telekomunikasi dalam P\&P. Berdasarkan Peringkat Penerimaan Moersch (1995) dapat dirumuskan bahawa tahap penerimaan perisian kursus dalam kalangan guru Matematik berada pada tahap sederhana.

Jadual 3

Deskriptif Penerimaan Perisian Kursus

\begin{tabular}{lcccc}
\hline Pemboleh ubah & Maksimum & Minimum & Min & $\begin{array}{c}\text { Sisihan Piawai } \\
(\mathrm{sp})\end{array}$ \\
\hline $\begin{array}{l}\text { Penerimaan } \\
\text { perisian kursus }\end{array}$ & 5.75 & 1.00 & 3.42 & 0.85 \\
\hline
\end{tabular}

\section{Pengaruh Faktor Perspektif Persekitaran Rogers terhadap Penerimaan Perisian Kursus}

Jadual 4 menunjukkan analisis regresi berganda untuk mengenal pasti pengaruh faktor perspektif persekitaran Rogers terhadap tahap penerimaan perisian kursus.

Dapatan kajian (Jadual 2) faktor perspektif persekitaran Rogers (Sokongan \& Masa) mempunyai pengaruh yang signifikan terhadap tahap penerimaan perisian kursus $(\beta=0.20)$ dalam kalangan guru Matematik. Faktor perspektif persekitaran menyumbang sebanyak 60 peratus varians terhadap tahap penerimaan perisian kursus. Sumbangan varians 60 peratus ini boleh diterima pakai sebagai peramal (Gall, Gall, \& Borg, 2003).

Dapatan kajian ini adalah selaras dengan kajian oleh Groves dan Zemel (2000) dan Morris (2001) yang mendapati aspek sokongan seperti latihan tentang cara penggunaan sesuatu teknologi, dan sokongan pihak pentadbiran adalah faktor-faktor yang penting yang mempengaruhi penggunaan teknologi dalam pendidikan. Di samping itu, kajian-kajian oleh Groves dan Zemel (2000), Norhayati 
(2000) dan Sima, Jayakaran dan Roselan (2009) juga menyokong dapatan kajian ini, di mana mereka mendapati masa memainkan peranan yang penting dalam mempengaruhi penerimaan sesuatu inovasi.

Jadual 4

Analisis Regresi Berganda Pengaruh Faktor Perspektif Persekitaran Rogers terhadap Penerimaan Perisian Kursus

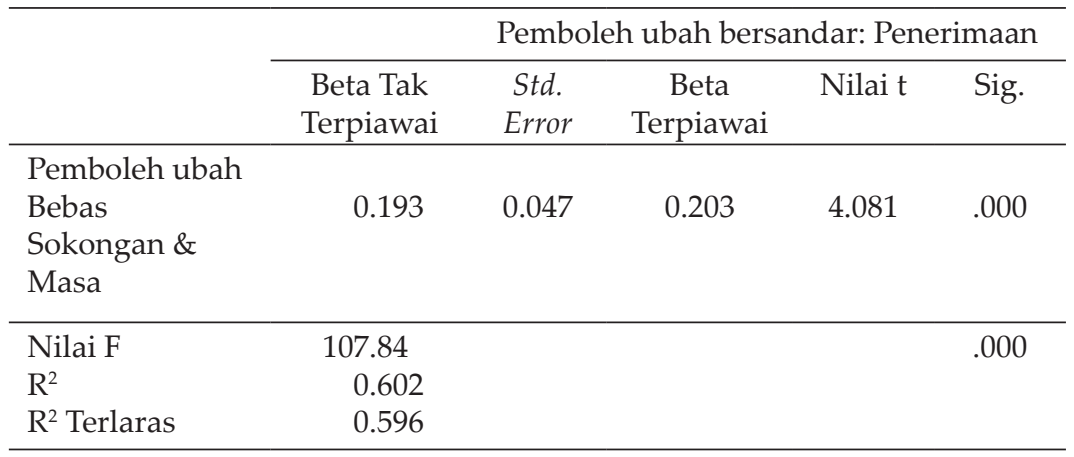

Sig. pada $p<.05$.

Dapatan ini menjelaskan bahawa guru-guru memerlukan galakan daripada pihak pentadbir sekolah, latihan yang berterusan dan kemudahan yang mencukupi supaya dapat mengintegrasikan sepenuhnya perisian kursus dalam P\&P. Guru-guru juga memerlukan masa yang secukupnya untuk merancang dan membuat persediaan mengajar dengan menggunakan perisian kursus supaya dapat meningkatkan lagi keberkesanan penggunaan perisian kursus dalam P\&P.

\section{Umur Guru sebagai Moderator terhadap Hubungan antara Faktor Perspektif Persekitaran Rogers dengan Penerimaan Perisian Kursus}

Jadual 5 menunjukkan keputusan interaksi pemboleh ubah umur sebagai moderator terhadap hubungan antara faktor Perspektif Persekitaran Rogers dengan tahap penerimaan perisian kursus.

Langkah 1 dalam analisis regresi berganda hierarki yang melibatkan faktor Sokongan dan Masa menunjukkan 77 peratus varians $\left(\mathrm{R}^{2}\right)$ dapat dijelaskan oleh pemboleh ubah bebas tersebut terhadap penerimaan perisian kursus. Dapatan menunjukkan faktor Sokongan 
IJMS 21 (1), 127-146 (2014)

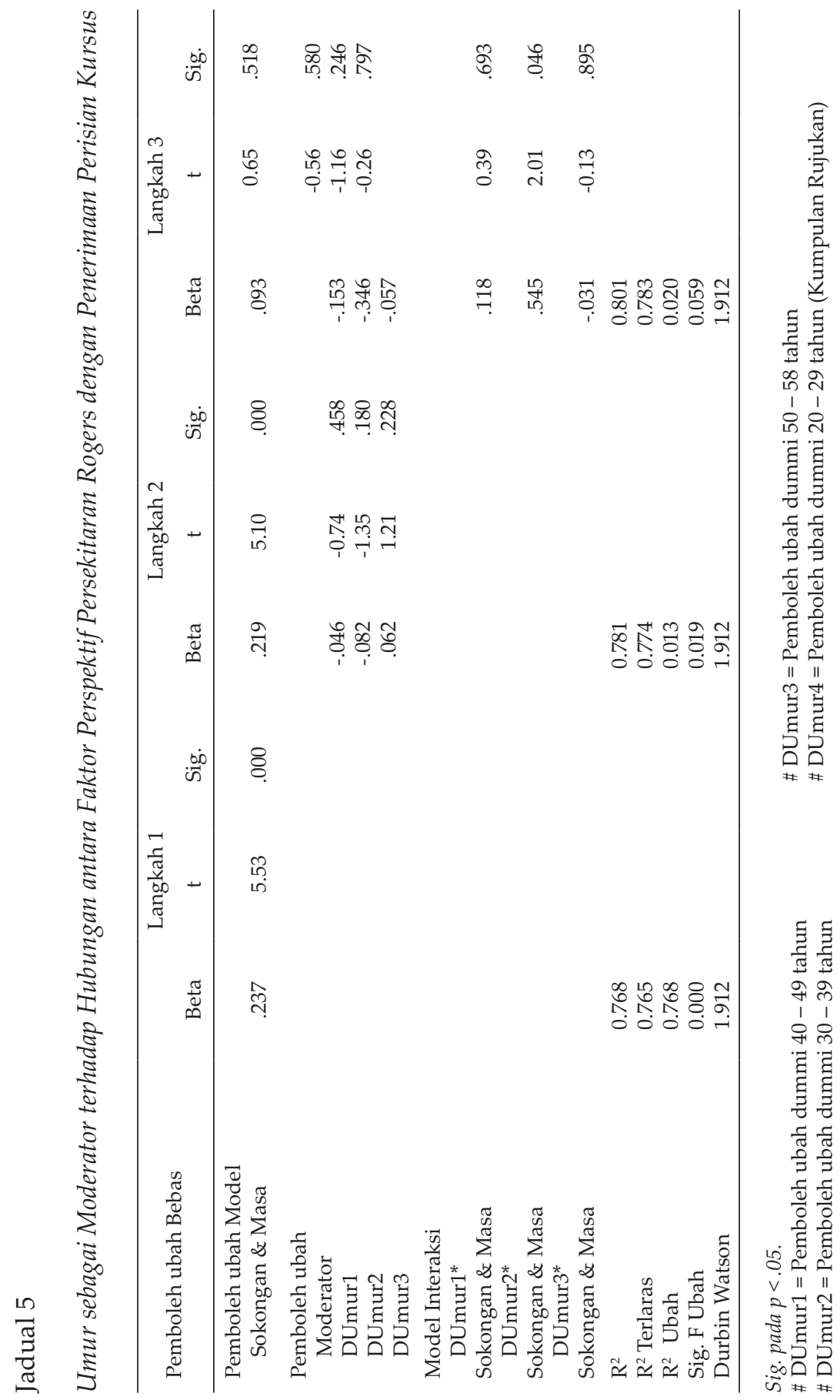


dan Masa $(\beta=0.237, t=5.53, p=0.000)$ mempunyai hubungan yang positif dan pengaruh yang signifikan terhadap tahap penerimaan perisian kursus. Ini menjelaskan bahawa satu unit pertambahan kepada Sokongan dan Masa akan memberi pertambahan kepada nisbah kebarangkalian tahap penerimaan perisian kursus.

Dapatan Langkah 2 pula menunjukkan pemboleh ubah moderator DUmur dapat menjelaskan 78 peratus varians $\left(R^{2}\right)$ terhadap tahap penerimaan perisian kursus. Walau bagaimanapun, pemboleh ubah DUmur1, DUmur2 dan DUmur3 tidak mempunyai hubungan yang signifikan dengan tahap penerimaan perisian kursus. Nilai koefisien pemboleh ubah DUmur1 (-0.05) dan DUmur2 (-0.08) menunjukkan bahawa guru yang berumur antara 40 hingga 49 tahun dan 30 hingga 39 tahun mempunyai pengaruh yang lebih rendah terhadap tahap penerimaan perisian kursus berbanding guru yang berumur 20 hingga 29 tahun kerana koefisien adalah negatif. Manakala dapatan menunjukkan guru yang berumur 50 hingga 58 tahun mempunyai pengaruh yang lebih tinggi terhadap tahap penerimaan perisian kursus berbanding guru yang berumur 20 hingga 29 tahun kerana koefisien adalah 0.06 .

Analisis interaksi antara pemboleh ubah moderator umur dan pemboleh ubah bebas dalam Langkah 3 menunjukkan $\mathrm{R}^{2}$ telah meningkat kepada 80.1 peratus. Dapatan menunjukkan hanya terdapat satu interaksi yang mempunyai pengaruh pemboleh ubah moderator umur yang signifikan terhadap hubungan antara faktor perspektif persekitaran Rogers dengan tahap penerimaan perisian kursus iaitu interaksi antara DUmur2 dan Sokongan dan Masa $(\beta=$ $0.545, \mathrm{t}=2.01, p=0.046$ ) dan hubunganya adalah positif.

Rajah 2 menunjukkan interaksi antara Sokongan dan Masa, dan Umur terhadap tahap penerimaan perisian kursus. Dapatan menunjukkan terdapat hubungan yang kuat antara faktor Sokongan dan Masa dengan tahap penerimaan apabila umur guru adalah antara 20 hingga 29 tahun. Secara keseluruhannya, Rajah 2 menunjukkan tidak terdapat perbezaan ketara pada tahap penerimaan apabila Sokongan dan Masa rendah. Tetapi perbezaan ketara dapat dilihat apabila Sokongan dan Masa tinggi. Dalam kata lain, apabila Sokongan dan Masa tinggi guru-guru dalam pelbagai kategori umur melaporkan tahap penerimaan yang lebih tinggi berbanding keadaan apabila Sokongan dan Masa rendah. 
IJMS 21 (1), 127-146 (2014)

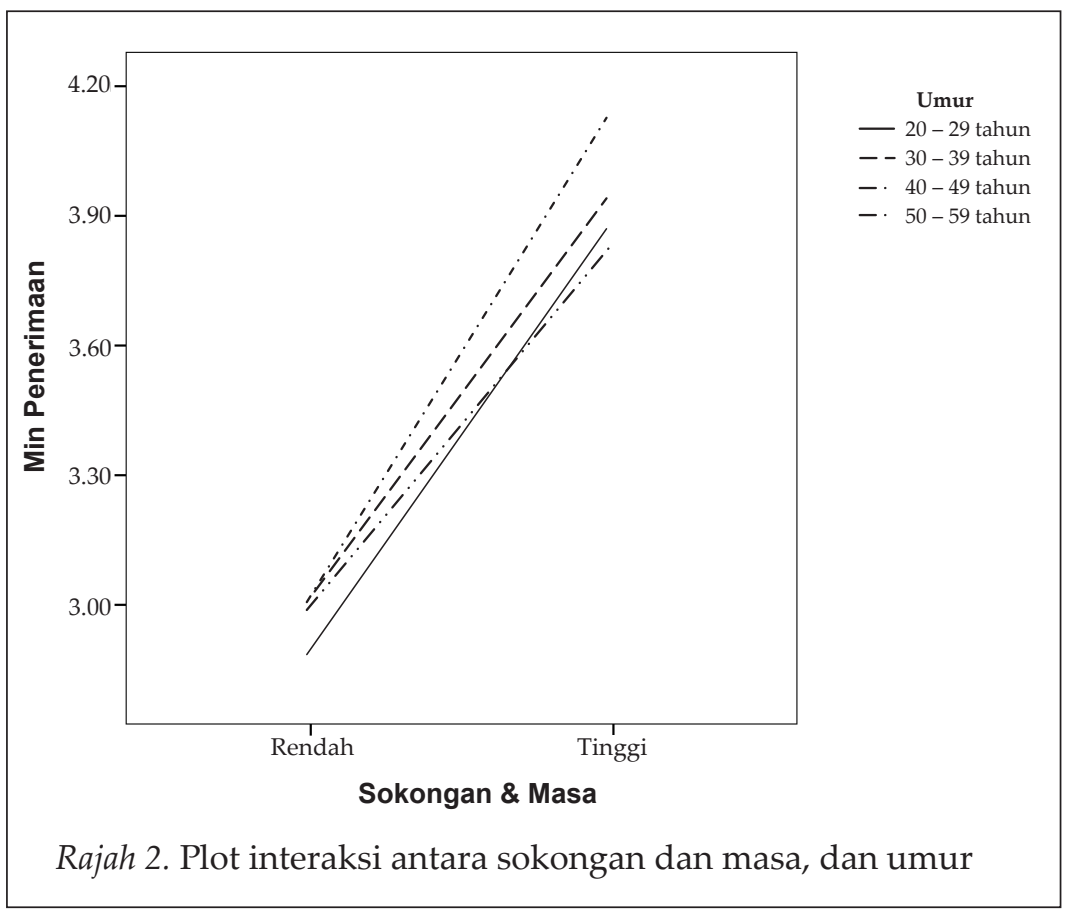

Hasil kajian ini menunjukkan bahawa pemboleh ubah umur sebagai moderator telah memberi pengaruh yang signifikan terhadap hubungan antara perspektif persekitaran Rogers dengan tahap penerimaan perisian kursus. Dapatan kajian ini adalah selaras dengan kajian oleh Shahrinaz (2009) yang juga mendapati faktor umur sebagai pemboleh ubah moderator telah memberi sumbangan kepada peningkatan penerimaan teknologi blog.

Selain itu, dapatan menunjukkan terdapat hubungan yang kuat antara faktor Sokongan dan Masa dengan tahap penerimaan apabila umur guru adalah antara 20 hingga 29 tahun. Ini berkemungkinan disebabkan oleh guru-guru yang berumur antara 20 hingga 29 tahun telah diberi pendedahan awal kepada ICT dan aplikasinya daripada peringkat sekolah mahu pun semasa di institusi pengajian tinggi. Oleh itu, guru dalam peringkat unur ini mempunyai kemahiran ICT yang baik dan lebih yakin dalam mengintegrasikan perisian kursus dalam P\&P dengan berkesan.

Dalam model regresi berganda dengan pemboleh ubah dummi, dapatan kajian menunjukkan guru yang berumur antara 40 hingga 
49 tahun dan 30 hingga 39 tahun mempunyai pengaruh yang lebih rendah terhadap tahap penerimaan perisian kursus berbanding guru yang berumur 20 hingga 29 tahun. Manakala guru yang berumur 50 hingga 58 tahun pula mempunyai pengaruh yang lebih tinggi terhadap tahap penerimaan perisian kursus berbanding guru yang berumur 20 hingga 29 tahun. Dapatan kajian ini bertentangan dengan kajian oleh Phang (1998) yang mendapati walaupun guru yang lebih berumur mempunyai sikap yang positif terhadap komputer tetapi tahap penerimaan komputer mereka adalah lebih rendah berbanding dengan guru yang muda.

Perbezaan dapatan kajian ini berkemungkinan disebabkan oleh faktor perubahan masa. Pelaksanaan program Pengajaran dan Pembelajaran Sains dan Matematik dalam Bahasa Inggeris (PPSMI) telah menyebabkan guru-guru daripada pelbagai kategori umur telah diberi latihan untuk mengintegrasikan perisian kursus dalam P\&P. Memandangkan guru-guru yang lebih tua telah mempunyai sikap yang positif terhadap ICT, apabila ditambah dengan kemahiran ICT turut mempengaruhi peningkatan tahap penerimaan perisian kursus. Di samping itu, tahap kebimbangan guru-guru yang lebih tua terhadap ICT juga berkemungkinan merupakan salah punca peningkatan tahap penerimaan perisian kursus dalam kalangan guru yang berumur 50 hingga 58 tahun.

Perbezaan ketara dalam tahap penerimaan perisian kursus dapat ilihat apabila Sokongan dan Masa adalah tinggi. Apabila Sokongan dan Masa tinggi, guru-guru dalam pelbagai kategori umur melaporkan tahap penerimaan yang lebih tinggi berbanding keadaan apabila Sokongan dan Masa rendah. Ini menjelaskan bahawa walaupun guru datang daripada pelbagai kategori umur mereka masih memerlukan sokongan dalam bentuk galakan dan kemudahan ICT yang lengkap serta masa yang mencukupi untuk mengintegrasikan perisian kursus dalam P\&P dengan berkesan.

\section{Implikasi Kajian}

Tahap penerimaan perisian kursus dalam kalangan guru Matematik yang mengajar Tingkatan 1 di SMK harian berada pada peringkat ketiga iaitu Peringkat Penerapan. Dengan itu, dapat dirumuskan bahawa tahap penerimaan perisian kursus dalam kalangan guru Matematik yang mengajar Tingkatan 1 berada pada tahap sederhana. Ini menjelaskan bahawa proses pendifusian dan faktor Perspektif 
Persekitaran Rogers mempunyai hubungan signifikan dengan tahap penerimaan perisian kursus perlu diberi lebih penekanan supaya dapat meningkatkan lagi tahap penerimaan dalam kalangan guru Matematik. Hal ini kerana Moersch (1995) berpendapat bahawa peningkatan penerimaan teknologi dalam pengajaran akan menyebabkan guru mencapai peringkat penerimaan yang lebih tinggi.

Selain itu, dapatan kajian ini telah menjelaskan faktor Perspektif Persekitaran Rogers mempunyai pengaruh yang signifikan terhadap penerimaan perisian kursus. Dapatan ini menunjukkan bahawa guru Matematik memerlukan sokongan dari segi latihan tentang cara penggunaan perisian kursus dalam P\&P, sokongan pihak pentadbiran dalam bentuk galakan kepada guru untuk menggunakan perisian kursus dalam P\&P dan sokongan teknikal. Di samping itu, guru juga memerlukan masa yang mencukupi untuk mempelajari cara menggunakan perisian kursus dan membuat persediaan untuk mengajar dengan menggunakan teknologi tersebut. Dapatan ini secara tidak langsung berkait dengan kajian oleh Poe (2000) yang berpendapat beban tugas guru yang mengajar Matematik, perlu dikurangkan supaya mereka mempunyai masa untuk meneroka inovasi baru dan mengaplikasikannya dalam P\&P.

Di samping itu, dapatan kajian ini mengenal pasti faktor umur guru sebagai moderator antara faktor Perspektif Persekitaran Rogers dengan tahap penerimaan perisian kursus. Oleh itu, adalah penting semasa mendifusikan perisian kursus faktor umur guru diberi penekanan supaya interaksi antara umur guru dengan Sokongan dan Masa dapat meningkatkan lagi tahap penerimaan perisian kursus dalam kalangan guru Matematik. Guru-guru daripada pelbagai kategori perlu diberi peluang untuk mengikuti latihan berasaskan ICT dan perlu diberi galakan untuk mengintegrasikan ICT dalam P\&P.

Sementara kepada pembuat dasar, khususnya Kementerian Pelajaran Malaysia, perlu memberikan perhatian perlu dalam memastikan keberkesanan proses pendifusian dan penerimaan inovasi perisian kursus. Pihak kementerian juga harus memberi sokongan dan galakan sepenuhnya kepada pengintegrasian perisian kursus dalam P\&P. Dengan adanya sokongan dan galakan ini, guru-guru Matematik akan mempunyai minat dan semangat untuk mengaplikasikan perisian kursus dalam pengajaran dengan berjaya. 


\section{Cadangan Kajian Lanjutan}

Kajian tentang pengaruh faktor perspektif persekitaran Rogers terhadap tahap penerimaan perisian kurus juga boleh dijalankan ke atas guru-guru mata pelajaran lain seperti Sains. Dengan itu, penyelidik dapat mengenal pasti peringkat penerimaan perisian kursus dalam kalangan guru Sains serta pengaruh faktor perspektif persekitaran terhadap tahap penerimaan tersebut.

Di samping itu, dalam kajian ini penyelidik hanya menggunakan kaedah soal selidik sahaja untuk mengumpul data. Kajian lanjutan dicadangkan supaya menggunakan kaedah lain seperti kaedah pemerhatian, uji kaji atau temu bual untuk mendapatkan maklumat yang lebih lengkap dan terperinci.

Kajian lanjutan juga dicadangkan untuk menggunakan analisis kajian seperti Structural Equation Modeling (SEM) untuk melihat kesan interaksi antara pemboleh ubah-pemboleh ubah kajian dengan tahap penerimaan perisian kursus untuk menguatkan lagi model yang dibina.

\section{Rumusan}

Secara kesimpulannya, dapatan kajian ini menunjukkan bahawa penerimaan perisian kursus dalam kalangan guru Matematik yang terlibat dalam kajian ini berada pada peringkat ketiga iaitu Peringkat Penerapan. Dapatan kajian juga menunjukkan perspektif persekitaran Rogers (Sokongan \& Masa) dapat mempengaruhi tahap penerimaan perisian kursus dalam kalangan guru Matematik. Oleh yang demikian, faktor tersebut perlu dititikberatkan semasa mendifusikan perisian kursus supaya dapat meningkatkan lagi tahap penerimaannya.

Selain itu, pemboleh ubah umur telah dikenal pasti sebagai moderator yang memberi pengaruh yang signifikan terhadap hubungan antara faktor perspektif persekitaran Rogers dengan tahap penerimaan perisian kursus. Ini menjelaskan bahawa pemboleh ubah umur juga perlu diberi perhatian dalam proses pendifusian inovasi supaya dapat menyumbang kepada peningkatan tahap penerimaan perisian kursus. Peningkatan tahap penerimaan akan menyebabkan seorang 
guru beralih dari satu peringkat ke satu peringkat berdasarkan penggunaan teknologi dalam P\&P (Moersch, 2001). Keseluruhannya analisis regresi menunjukkan model yang digunakan adalah sah dan boleh diterima.

\section{Rujukan}

Askar, P., \& Usluel, Y. K. (2005). Diffusion of computers in schools. Encyclopedia of Distance Learning, 4, 568-572.

Azizah, J. (2006). Penggunaan perisian kursus Sekolah Bestari dalam kalangan guru dan pelajar sekolah di Malaysia. Prosiding Seminar IT Malaysia (SITMA 2006). 18-19 Ogos 2006. Terengganu: Primula Beach Resort.

Bee, T. L., \& Chia, H. S. (2008). Exploring the extent of ICT adoption among secondary school teachers in Malaysia. International Journal of Computing and ICT Research, 2(2), 19-36.

Davis, F. D., Bagozzi, R. P., \& Warshaw, P. R. (1989). User acceptance of computer technology: A comparison of two theoretical models. Management Science, 35(8), 982-1003.

Farquhar, J. D., \& Surry, D. W. (1997). Diffusion theory and instructional technology. Journal of Instructional Science and Technology, 2(1), 24-36.

Fong, S. K. (2006). ICT support for science and mathematics teachers in the implementation of ETeMS. Dicapai daripada http://www. deakin. edu.

Gall, M. D., Gall, J. P., \& Borg, W. R. (2003). Educational research: An introduction (7th ed.). Boston: Allyn \& Bacon.

Groves, M., \& Zemel, P. (2000). Instructional technology adoption in higher education: An action research case study. International Journal of Instructional Media, 27(1), 57-65.

Henderson, L., \& Putt, I. (1993). The remote area teacher education program (RATEP): Cultural contextualization of distance education through interactive multimedia. Distance Education, 14(2), 213-231.

Kementerian Pelajaran Malaysia (KPM). (2001). Penggunaan Teknologi Maklumat dan Komunikasi (ICT) dalam pengajaran dan pembelajaran. Kuala Lumpur: Pusat Perkembangan Kurikulum.

Krejcie, R. V., \& Morgan, D. W. (1970). Determining sample size for research activities. Educational and Psychological Measurement, $30,607-610$.

Lee, M. K. O., Cheung, C. M. K., \& Chen, Z. (2005). Acceptance of Internet-based learning medium: The role of extrinsic and intrinsic motivation. Information \& Management, 42, 1095-1104. 
Moersch, C. (1995). Levels of Technology Implementation (LoTi): A framework for measuring classroom technology use. Learning and Leading with Technology, 23(3), 40-42.

Moersch, C. (2001). Next steps: Using LoTi as a research tool. Learning $\mathcal{E}$ Leading with Technology, 29(3), 22-27.

Morris, R. (2001). Online tables of contents for books: The user's perspective (Unpublished doctoral dissertation). University of Michigan.

Norhayati, A. M. (2000). Computer technology in Malaysia: Teacher's background characteristics, attitudes and concerns. The Electronic Journal on Information Systems in Developing Countries, 3(8), 1-13.

Phang, Y. M. (1998). Computer usage among Secondary School Teachers (Unpublished master thesis). Sintok: Universiti Utara Malaysia.

Poe, M. E. (2000). Selected factors affecting attitudes of graduate faculty toward use of two-way audio/two-way video as a primary instructional delivery system (Unpublished doctoral dissertations). Texas A\&M University.

Pusat Perkembangan Kurikulum. (2006). The latest status of delivery, installation and usage of GSP in school. Kuala Lumpur: Kementerian Pelajaran Malaysia.

Roblyer, M. D., \& Edwards, J. (2000). Integration educational technology into teaching. Upper Saddle River: Prentice Hall.

Rogers, E. M. (2003). Diffusion of innovations (5th ed.). New York: The Free Press.

Sekaran, U. (2003). Research methods for business: A skill-building approach (4th ed.). United States of Amerika: John Wiley \& Sons.

Shahrinaz, I. (2009). Students acceptance in using blog as learning tool in an international private university. Prosiding ICI9. International Conference on Information. 12-13 Ogos 2009. Kuala Lumpur: The Legend Hotel.

Sima, S., Jayakaran, M., \& Roselan, B. (2009). Exploring the factors influencing UPM english language faculty members' adoption and integration of Web-Based Instruction (WBI). Journal of College Teaching \& Learning, 6(6), 31-38.

Siti Norazlina, K. (2008). Halangan terhadap penggunaan komputer dan ICT di dalam pengajaran dan pembelajaran (PEP) di kalangan guru di Sekolah Menengah Kebangsaan Luar Bandar di daerah Kulai Jaya, Johor (Kertas Projek Sarjana Muda yang tidak diterbitkan). Johor: Universiti Teknologi Malaysia.

Wiersma, W. (2000). Research methods in education: An introduction (7th ed.). Boston: Allyn and Bacon.

Webb, L. (2011). Supporting technology integration: The school administrators' role. In National Forum of Educational Administration \& Supervision Journal, 28(4), 1-7. 